\title{
A challenge awaits foresters in the jungles of Borneo
}

In February 1971 G. V. WELLBURN was part of a 12-man team that made a study of the economic potential of a forest area in Indoesia. His speciality was logging methods, costs and machinery.

Can the jungles of Borneo, one of the last great untapped reserves of wood, be developed without destruction? Will they provide the jobs, foreign investment and revenue which is so necessary to raise the standard of living of the people? Will a shelterwood or selective cutting system, where only the valuable trees are cut and the weeds are left, reproduce a second crop? Will economical logging cause serious erosion? These are some of the problems that occurred to me when I visited a newly formed logging operation near Balikpapan in the Kalamantan, the Indonesian part of the Island.

The jungle areas of Kalamantan and Sumatra are divided into concessions which are similar to a 20 year timber sale in British Columbia. They include a large enough area, up to 10,000 square miles, to allow the owner to develop a semi permanent operation. The agreement allows the export of raw logs during the initial period but requires the construction of manufacturing plants at a later date. The holder of the concession is expected to abide by the labour laws, to employ and train local people and to provide housing, schools and hospitals. These stipulations add significantly to the amount of capital required by the foreign investor and increase his vulnerability in case of political change or excessive demands from the civil service.

The area I visited near Balikipan was gentle and rolling with elevations from sea level to 2000 feet. Other than a few limestone ridges and some sandstone outcrops, the soil is a red clay. There is no humus and no gravel, simply decaying leaves and mud.

The forest is a mixture of tropical hardwoods, but only the Merante species, comprising about $40 \%$ of the forest, are logged. Trees of $6 \mathrm{ft}$ in diameter and $90 \mathrm{ft}$ to the first limb are common.
Volumes of saleable timber vary from 8 to 12 cunits per acre $\left(60-80 \mathrm{~m}^{3} / \mathrm{ha}\right)$. Other species are so scattered that they would be uneconomic to market or will not float in water and therefore cannot be floated to ships prior to loading.

Surprisingly, the "impenetrable' jungle is easy to walk through; the ground is relatively clear except for the swamps where navigation on foot is impossible. Although the large trees are spaced out, their full crowns shade the ground. Ferns, vines and bamboo are everywhere but they are not too dense when compared with the salal, huckleberry or salmon berry of Vancouver Island. The main inconvenience is the thorns - they have a variety of species like the devils club or worse.

Road building presents the major logging problem. Sub-grade which is constructed with D-8 size tractors hardens well in the sun but is impossibly slippery for any wheeled vehicle when it rains. In fact, it was so slippery that we had difficulty walking and the mud built up on our boots. The only solution is to surface with crushed limestone rock as there is no gravel and the sandstone is useless. The limestone quarry sites are rare so trucking distances can be great. Fortunately the rock crushes well in a 3 -inch primary crusher and only 3-4 inches are required to produce a good road. A complete road system is required to harvest the scattered timber, so the cost per cunit of wood is high.

Because of the rolling ground and big scattered timber, Kalamantan is a natural tractor-skidding show. Crawlers of the D-7 type work well. The rubber-tired Timberjacks worked in Sumatra but were not so successful in the mud of Borneo. Truck loading with large front-end loaders is more successful than with heel boom loaders, mainly because of difficulty in operation and maintenance. These crane loaders will be useful for uphill logging on steep slopes where the line can be pulled out by hand and attached to the logs. Trucks are conventional west coast type; a few war surplus Canadian Army Fords are still in operation. Par buckle dumps with jin poles are common and booming for towing to ships side is conventional.

Felling was mostly with power saws but some axe fallers still exist. A scaffold is built around the base of the tree and the cut is made about $6 \mathrm{ft}$ above the ground to avoid the butt swell. These fallers face all the hazards and problems of hangups from interlaced limbs that fallers face on the Pacific coast of B.C.

Most yarding is full stem length. At the landing the stem is bucked into logs and debarked with axes by a large crew. Debarking reduces shipping charges and the chance of insect attack. Logs for export are very high grade. All breaks and rot are bucked out and most trees are long butted to eliminate any flare. Each log is numbered in the landing, recorded at the dump and again recorded at shipside.

Merante logs are exported to Japan to be sold as Philippine mahogany. The logs sell for $\$ 25-$ $35 / \mathrm{m}^{3}$ along side the ship at $\mathrm{Ba}$ likapan. This works out to $\$ 70-85$ per cunit or roughly $\$ 125-150$ per MBM, which is exactly the same price we receive for the best quality Douglas-fir, cypress or Sitka spruce when exported.

Logging in Borneo is technically straight forward. Special problems of personnel training and parts availability exist but the big immediate problems are acquiring sufficient capital, and dealing with the politicians and civil servants. The chief long range problem is political stability.

It is the future of the forest itself that concerns me, I saw thousands of acres that had been slashed, burned, farmed and then abandoned to grass. The jungle does not grow back. What will be the effect of logging? No-one seems to know. Now is the time, when commercial logging is just beginning, for foresters to accept the challenge and to plan for the productive economic harvest of the jungles of Borneo. 